\title{
HEALTH LITERACY IN THE ELDERLY
}

\section{ZDRAVSTVENA PISMENOST U POPULACIJI STARIH OSOBA}

\author{
Jelena Brcanski', Aleksandra Jović Vraneš²
}

\section{Summary}

Aging of the population is particularly notable in high-income countries, while the vulnerability of elderly is well described in the literature. Cognitive and social skills decline during the aging process, which affects the level of health literacy. Health literacy refers to the ability to obtain, process and understand basic health information, and act upon information within the healthcare system. Elderly with an adequate level of health literacy are empowered to manage their health, as opposed to those with a low level of health literacy who have the greater chance of developing chronic illnesses and premature death. Also, elderly with low level of health literacy rarely use preventive services, but seek emergency services more often, they know less about their basic chronic illness and are more often faced with difficulties in managing their own disease. They have worse health outcomes and self-perception of health than those with adequate health literacy. This indicates the necessity of creating specific interventions aimed to improve the health outcomes of older people.

Key words: health literacy; elderly; health outcomes

\section{Sažetak}

Trend starenja populacije je posebno izražen u visokorazvijenim zemljama, dok je vulnerabilnost populacije starih dobro opisana u literaturi. Starenjem opadaju kognitivne i socijalne veštine, što se dovodi u vezu sa nivoom zdravstvene pismenosti i zdravstvenim ishodima. Zdravstvena pismenost se odnosi na mogućnost čitanja, razumevanja i postupanja prema informacijama u okviru sistema zdravstvene zaštite. Starije osobe sa adekvatnim nivoom zdravstvene pismenosti su osnažene da upravljaju svojim zdravljem, za razliku od starijih osoba sa niskim nivoom zdravstvene pismenosti koje imaju veću šansu za razvoj hroničnih bolesti i prevremenu smrt. Takođe starije osobe sa niskim nivoom zdravstvene pismenosti ređe koriste preventivne usluge, češće koriste hitne službe, manje znaju o svojoj osnovnoj hroničnoj bolesti, teže upravljaju bolešću i lošije procenjuju sopstveno zdravlje. Sve navedeno ukazuje na potrebu da intervencije usmenene ka unapređenju zdravstvenih ishoda starije populacije, moraju biti specifično kreirane i prilagođene ovoj populacionoj grupi.

Ključne reči: zdravstvena pismenost; stare osobe; zdravstveni ishodi

\section{UvoD}

Svetska populacija osoba starijih od 60 godina, procenjena je na 962 miliona u 2017. godini, dok se 2050. godine očekuje da će ovaj broj preći vrednost od 2,1 milijarde (1). Globalni javno-zdravstveni izazov predstavljen od strane Svetske zdravstvene organizacije, još 2012. godine, bio je starenje populacije, u smislu suočavanja planete sa demografskom transformacijom koja primorava i najrazvijenije države sveta da sprovedu reforme svojih sistema, kako bi ih prilagodili potrebama ove populacione grupe (2).

Termin "zdravstvena pismenost” označava kognitivne i društvne veštine koje određuju motivaciju i mogućnost pojedinca da pristupi, razume i koristi informacije na način koji će promovisati i održavati dobro zdravlje (3). Kognitivne veštine se tokom života menjaju i udružene sa ostalim individualnim i faktorima sredine, utiču na nivo zdravstvene pismenosti pojedinca (4-7). Ovaj problem može predstavljati izazov kreatorima zdravstvene politike, u smislu iznalaženja najboljih strategija za unapređenje zdravlja starih osoba, te je pitanje povezanosti zdravstvene pismenosti sa zdravstvenim ishodima i mortalitetom ove populacione grupe vrlo aktuelan i značajan sa aspekta unapređenja zdravstvenih ishoda.

Cilj ovog malog preglednog rada je da opiše postojeće teorije i modele, kao i da razmotri oblasti od interesa za izučavanje povezanosti nivoa zdravstvene pismenosti sa mortalitetom i zdravstvenim statusom starih osoba, ali i da analizira postojeće preporuke koje se odnose na dalja istraživanja u ovoj oblasti.

\section{ZDRAVSTVENA PISMENOST - TEORIJSKI KONCEPT}

Jedna od prvih definicija zdravstvene pismenosti odnosila se na mogućnost čitanja, razumevanja i postupanja prema informacijama u okviru sistema zdravstvene zaštite. Ovaj kratak i sažet pristup korišćen je u studiji o pismenosti odraslih u SAD-u, koja je sprovedena u toku 1992. godine (8). Komitet Američke medicinske asocijacije za zdravstvenu pismenost, The Ad Hoc Committee on Health Literacy for the Council on Scientific Affairs of the American Medical Association, odlučio se za nešto širi pogled baziran na veštinama kada je reč o zdravstvenoj pismenosti (9). Za razliku od njih, strategija 
„Zdravi ljudi SAD 2010“, US Healthy People 2010, povezuje zdravstvenu pismenost sa promocijom zdravlja i ponašanjem osoba, te ona prevazilazi domen funkcionalnog obrazovanja (10).

Na petoj Globalnoj konferenciji o promociji zdravlja, definicija zdravstvene pismenosti je proširena, tako da obuhvata dimenzije razvoja zajednice, kao i veštine vezane za zdravlje izvan opsega promocije zdravlja. Zdravstvena pismenost se sagledava, ne samo kao lična karakteristika, već i kao ključna determinanta zdravlja populacije (11).

Međutim, definisanje zdravstvene pismenosti još uvek nije uniformno, odnosno ne postoji opšte prihvaćena definicija zdravstvene pismenosti, što predstavlja stalni izazov naučnicima da definišu, u najboljoj meri, ovu kategoriju.

Sjorensen i saradnici su dali pregled postojećih definicija zdravstvene pismenosti u cilju boljeg razumevanja i iznalaženja najadekvatnijeg modela za objašnjavanje ovog pojma. Pomenuti autori nakon pregleda postojećih definicija, definišu zdravstvenu pismenost na način da je povezuju s opštom pismenošću i uključuju znanja ljudi, njihovu motivaciju i kompetencije za pristup, razumevanje, procenjivanje i primenu informacija o zdravlju, kako bi se donosili pravi sudovi i odluke u svakodnevnom životu, uključujući one koje se odnose na zdravstvenu zaštitu, prevenciju bolesti i promociju zdravlja, a sve u cilju održavanja ili unapređenja kvaliteta života tokom životnog ciklusa (12).

Postoji više opisanih modela zdravstvene pismenosti: Zdravstvena pismenost kao dobro, koji karakteriše razvoj veština neophodnih za različite forme zdravstvenih akcija; Zdravstvena pismenost kao rizik, koji je usmeren na razvoj ličnog znanja i mogućnosti, kao i interpersonalnih i društvenih veština (13).

\section{ZDRAVSTVENA PISMENOST STARIH}

S obzirom da kognitivne funkcije tokom starenja opadaju i utiču na nivo zdravstvene pismenosti pojedinca (4-7), studije koje se bave populacijom starih opisuju zdravstvenu pismenost kao rizik, odnosno zaključuju da slabije kognitivne funkcije doprinose povećanju mortaliteta (14-17), češćem koriščenju hitnih službi (18), slabijem korišćenju preventivnih usluga $(19,20)$, manjem znanju o osnovnoj hroničnoj bolesti, težem upravljanju bolešću i lošijoj proceni sopstvenog zdravstvenog stanja $(16,17,20-23)$.

Studija objavljena 2015. godine, koja je sprovedena u američkim državama Nevada, Kalifornija i Kentaki utvrdila je povezanost između nivoa zdravstvene pismenosti i zdravstvenih ishoda kod starih osoba, a kao glavni zaključak je akcentovala da intevencije usmerene ka poboljšanju zdravstvenih ishoda kod starijih osoba sa kardiovaskularnim poremećajima moraju uključiti ak- tivnosti koje se odnose na unapređenje nivoa zdravstvene pismenosti (24). Sa druge strane studija sprovedena u Japanu dokazala je, da je visok nivo zdravstvene pismenosti starih prediktivni faktor dobrog zdravlja, odnosno da je povezan sa izostankom slabosti. Studija ističe da sveobuhvatna zdravstvena pismenost može imati važnu ulogu u održavanju dobrog zdravstvenog statusa starijih osoba u zajednici (25). Studija sprovedena u Turskoj ukazala je da zdravstvena pismenost predstavlja problematičnu kariku u sprovođenju zdravstvene zaštite starih osoba. Posebno problematične oblasti, identifikovane u ovoj studiji, odnosile su se na pitanja sprovođenja vakcinacije i preventivnih pregleda u ovoj populacionoj grupi (26).

Brojne studije ukazuju na vezu zdravstvene pismenosti i zdravstvenih ishoda. Studija koja je procenjivala povezanost niskog nivoa zdravstvene pismenosti i mortaliteta kod starih osoba utvrdila je skoro 1,5 puta veću šansu od smrtnog ishoda osobama sa niskim nivoom zdravstvene pismenosti (14). Sledeća studija koja se bavila vezom mortaliteta i nivoa zdravstvene pismenosti utvrdila je značajano veći procenat umrlih ispitanika sa marginalnom i neadekvatnom zdravstvenom pismenošću u odnosu na ispitanike koji su imali adekvatan nivo zdravstvene pismenosti (15).

Američka studija sprovedena na populaciji starih ukazuje da osobe sa niskim nivoom zdravstvene pismenosti imaju niže prihode i niži nivo obrazovanja, takođe samopercepcija sopstvenog zdravlja im je lošija, imaju teškoće vezane za vid i sluh, potrebna im je pomoć pri popunjavanju dokumenata, čitanju novina ili pisanju, a takođe i manje koriste zdravstvene informacije. Sve ovo doprinosi razvoju nejednakosti koje su vezane za zdravstvene ishode starih osoba (27).

Koreanska studija koja je procenjivala nivo zdravstvene pismenosti kod starijih osoba, a koja je u vezi sa fukcionalnim zdravljem, utvrdila je da ispitanici sa niskim nivoom zdravstvene pismenosti češće imaju artritis i hipertenziju od ispitanika sa adekvatnim nivoom zdravstvene pismenosti, kao i da ispitanici sa niskim nivoom zdravstvene pismenosti lošije ocenjuju svoje fizičko i mentalno zdravlje od ispitanika sa adekvatnim nivoom zdravstvene pismenosti (21).

Osim zdravstvenih ishoda, autori studija su se bavili i procenom nivoa zdravstvene pismenosti kod starije populacije, koja je u vezi sa rizičnim ponašanjem. Dokazano je da u poređenju sa ispitanicima koji imaju adekvatan nivo zdravstvene pismenosti, oni sa neadekvatnim nivoom, se u većoj meri izjašnjavaju da nikada nisu pušili i da nikada nisu koristili alkoholna pića. Ispitanici sa neadekvatnim nivoom zdravstvene pismenosti češće imaju sedatorni način života. Međutim u ovoj studiji, nakon prilagođavanja, multivarijantna regresija nije pokazala značajnu povezanost nivoa zdravstvene pismenosti i rizičnog ponašanja (17). 
Studije predlažu istraživanja koja će biti postavljena tako da prate pojedinca kroz životni ciklus; ističu značaj komunikacije, edukacije i jednostavnog jezika u cilju smanjenja veličine povezanosti niskog nivoa zdravstvene pismenosti i zdravstvenih ishoda; predlažu razvijanje intervencija adekvatnih za populaciju starih; ističu značaj edukacije pacijenata od strane zdravstvenih radnika (17-31).

Pitanje povezanosti socijalne podrške i nivoa zdravstvene pismenosti ostaje diskutabilno (22). Takođe kroz studije je naglašeno da se zdravstvena pismenost ne shvata samo kao veština pojedinca, već kao determinanta zdravlja (19), kao i da se u istraživanjima obrati pažnja na pridružene faktore koji mogu uticati na veličinu povezanosti zdravstvene posmenosti sa zdravstvenim ishodima (17).

\section{ZAKLJUČAK}

Starije osobe u odnosu na mlađu populaciju imaju niži nivo zdravstvene pismenosti (18), te je povezanost ovog prediktora sa zdravljem strih pacijenata veoma visoka. Ovaj pregled ukazuje na opasnost da stare osobe sa nižim nivoom zdravstvene pismenosti slabije koriste preventivne usluge, takođe pregled ističe povezanost mortaliteta u ovoj populacionoj grupi sa nivoom zdravstvene pismenosti, kao i lošiju samopercepciju sopstvenog zdravlja, odnosno lošije zdravstvene ishode. Iako se u studijama navodi da je zdravstvenu pismenost potrebno posmatrati i kao determinantu zdravlja, skoro sve studije navode definiciju zdravstvene pismenosti koja je isključivo bazirana na karakteristikama i individualnim veštinama pojedinca.

\section{Literatura}

1. United Nations Department for Economic and Social Affairs. World Population Ageing 2017 Highlights. UN; 2019.

2. Shetty P. Grey matter: ageing in developing countries. The Lancet. 2012 Apr 7;379(9823):1285-7.

3. Nutbeam D. Health literacy as a public health goal: a challenge for contemporary health education and communication strategies into the 21st century. Health promotion international. 2000 Sep 1;15(3):259-67.

4. Murray C, Johnson W, Wolf MS, Deary IJ. The association between cognitive ability across the lifespan and health literacy in old age: The Lothian Birth Cohort 1936. Intelligence. 2011 Jul 1;39(4):178-87.

5. Kobayashi LC, Wardle J, Wolf MS, von Wagner C. Cognitive function and health literacy decline in a cohort of aging English adults. Journal of general internal medicine. $2015 \mathrm{Jul}$ 1;30(7):958-64.

6. Smith SG, O'conor R, Curtis LM, Waite K, Deary IJ, Paasche-Orlow $\mathrm{M}$, Wolf MS. Low health literacy predicts decline in physical function among older adults: findings from the LitCog cohort study. J Epidemiol Community Health. 2015 May 1;69(5):474-80

7. Wilson RS, Yu L, James BD, Bennett DA, Boyle PA. Association of financial and health literacy with cognitive health in old age. Aging, Neuropsychology, and Cognition. 2017 Mar 4;24(2):186-97.

8. Kirsch IS. Adult literacy in America: A first look at the results of the National Adult Literacy Survey. US Government Printing Office, Superintendent of Documents, Washington, DC 20402 (Stock No. 065000-00588-3).; 1993 Sep.

9. Hoc AD. Committee on Health Literacy for the American Council on Scientific Affairs, American Medical Association. Health literacy: Report of the council on scientific affairs. Jama. 1999;281(6):552-7.

10. United States. Department of Health, Healthy People 2010 (Group). Healthy people 2010. US Department of Health and Human Services, Healthy People 2010; 2000.

11. Kickbusch IS. Health literacy: addressing the health and education divide. Health promotion international. 2001 Sep 1;16(3):289-97.

12. Sørensen K, Van den Broucke S, Fullam J, Doyle G, Pelikan J, Slonska Z, Brand $\mathrm{H}$. Health literacy and public health: a systematic review and integration of definitions and models. BMC public health. 2012 Dec;12(1):80.

13. Nutbeam D. The evolving concept of health literacy. Social science \& medicine. 2008 Dec 1;67(12):2072-8.

14. Bostock S, Steptoe A. Association between low functional health literacy and mortality in older adults: longitudinal cohort study. Bmj. 2012 Mar 15;344:e1602.

15. Baker DW, Wolf MS, Feinglass J, Thompson JA, Gazmararian JA, Huang J. Health literacy and mortality among elderly persons. Archives of internal medicine. 2007 Jul 23;167(14):1503-9.

16. Sudore RL, Yaffe K, Satterfield S, Harris TB, Mehta KM, Simonsick EM, Newman AB, Rosano C, Rooks R, Rubin SM, Ayonayon HN. Limited literacy and mortality in the elderly. Journal of general internal medicine. 2006 Aug 1;21(8):806-12.

17. Wolf MS, Gazmararian JA, Baker DW. Health literacy and health risk behaviors among older adults. American journal of preventive medicine. 2007 Jan 1;32(1):19-24.

18. Baker DW, Gazmararian JA, Sudano J, Patterson M. The association between age and health literacy among elderly persons. The Journals of Gerontology Series B: Psychological Sciences and Social Sciences. 2000 Nov 1;55(6):S368-74.

19. Cho YI, Lee SY, Arozullah AM, Crittenden KS. Effects of health literacy on health status and health service utilization amongst the elderly. Social science \& medicine. 2008 Apr 1;66(8):1809-16.

20. Sudore RL, Mehta KM, Simonsick EM, Harris TB, Newman AB, Satterfield S, Rosano C, Rooks RN, Rubin SM, Ayonayon HN, Yaffe K. Limited literacy in older people and disparities in health and healthcare access. Journal of the American Geriatrics Society. 2006 May;54(5):770-6.

21. Kim SH. Health literacy and functional health status in Korean older adults. Journal of clinical nursing. 2009 Aug;18(16):2337-43.

22. Lee SY, Arozullah AM, Cho YI, Crittenden K, Vicencio D. Health literacy, social support, and health status among older adults. Educational gerontology. 2009 Feb 4;35(3):191-201.

23. Bennett IM, Chen J, Soroui JS, White S. The contribution of health literacy to disparities in self-rated health status and preventive health behaviors in older adults. The Annals of Family Medicine. 2009 May 1;7(3):204-11.

24. Wu JR, Moser DK, DeWalt DA, Rayens MK, Dracup K. Health literacy mediates the relationship between age and health outcomes in patients with heart failure. Circulation: Heart Failure. 2016 Jan;9(1):e002250.

25. Shirooka H, Nishiguchi S, Fukutani N, Adachi D, Tashiro Y, Hotta T, Morino S, Nozaki Y, Hirata H, Yamaguchi M, Aoyama T. Association between comprehensive health literacy and frailty level in community-dwelling older adults: A cross-sectional study in Japan. Geriatrics \& gerontology international. 2017 May;17(5):804-9.

26. Bozkurt H, Demirci H. Health literacy among older persons in Turkey. The Aging Male. 2018 Feb 10:1-6.

27. Cutilli CC, Simko LC, Colbert AM, Bennett IM. Health literacy, health disparities, and sources of health information in US older adults. Orthopaedic Nursing. 2018 Jan 1;37(1):54-65.

28. Scott TL, Gazmararian JA, Williams MV, Baker DW. Health literacy and preventive health care use among Medicare enrollees in a managed care organization. Medical care. 2002 May 1;40(5):395-404. 